Estonian Journal of Archaeology, 2021, 25, 1, 32-54

https://doi.org/10.3176/arch.2021.1.02

\author{
Elena R. Mikhaylova, Ivan G. Shirobokov, Kirill V. Shmelev, \\ Gleb K. Danilov, Aivar Kriiska and Dmitriy V. Gerasimov
}

\title{
BURIED IN THE DUNES: CREMATION OF THE MIGRATION PERIOD ROSSON 11 IN THE NARVA-LUGA KLINT BAY AREA
}

Received 20 August 2020, accepted 7 September 2020, available online 11 February 2021

Cremation burials of the 1st millennium AD were probably one of the most spread but the least studied funeral traditions in the north-west of Eastern Europe. In 2013, a single cremation Rosson 11 was found in a rather untypical landscape in the Narva-Luga Klint Bay area, by the Russian-Estonian border. The burial was located at the foot of Kudruküla palaeospit, $1 \mathrm{~km}$ away from the shoreline of the Baltic Sea, in a plain and marshy area. Burnt bones might have belonged to one individual, presumably 15-45 years old, most likely female, as judged from anthropological evidence and assemblage of the preserved burial goods. Cremation was done elsewhere, and the remains were afterwards placed in an urn and a shallow pit. Besides the burnt bones, the contents included fragments of bronze ornamented plates, of a narrow cast bracelet with a longitudinal rib, a fragment of an iron artefact, and fragments of hand-built pottery. The chronology of typologically pronounced finds allows to date the burial within 5th-6th c. AD. A burnt bone fragment was dated by AMS, within the interval from 420 to $560 \mathrm{cal}$ AD. The Rosson 11 burial differs from burials with stone constructions known in the Izhora Plateau, as well as from Pskov Long Barrows and eastern Lithuanian barrows, although there are many parallels to the bracelet and other finds from the site. This burial can be considered as an evidence that the population of Ingeria did use the coastal landscape in the second half of the 1st millennium AD.

Elena R. Mikhaylova, St.-Petersburg State University, 1/3-9 Smolnogo St., St.-Petersburg, Russia; helena.mikhaylova@gmail.com

Ivan G. Shirobokov, Peter the Great Museum of Anthropology and Ethnography /Kunstkamera/, Russian Academy of Sciences, 3 University emb., 199034 St.-Petersburg, Russia; ivansmith@bk.ru

Kirill V. Shmelev, St.-Petersburg State University, 1/3-9 Smolnogo St., St.-Petersburg, Russia; bamblebeec@mail.ru

Gleb K. Danilov, Peter the Great Museum of Anthropology and Ethnography /Kunstkamera/, Russian Academy of Sciences, 3 University emb., 199034 St.-Petersburg, Russia; gleb.danilov.spb@gmail.com

Aivar Kriiska, Department of Archaeology, Institute of History and Archaeology, University of Tartu, 18 Ülikooli St., 50090 Tartu, Estonia; aivar.kriiska@ut.ee 
Dmitriy V. Gerasimov, Peter the Great Museum of Anthropology and Ethnography /Kunstkamera/, Russian Academy of Sciences, 3 University emb., 199034 St.-Petersburg, Russia; dger@kunstkamera.ru

\section{Introduction}

In recent decades, archaeological investigations in the north-west of Eastern Europe were very prolific; however, there are still not enough studies in the antiquities of the second and third quarters of the 1st millennium AD (Late Roman Iron Age, Migration Period and Merovingian / Pre-Viking Period) in this territory. Archaeological sites of the time are located sparsely and studied unevenly. Some cultural units are represented by settlements only, while others are known mostly by excavated burial sites.

Funeral rites of the considered time in the north-west of Eastern Europe are represented by several types of burial sites (Fig. 1). Among those, burial barrows prevail, as they are easy to recognize in the landscape. The so-called Pskov Long

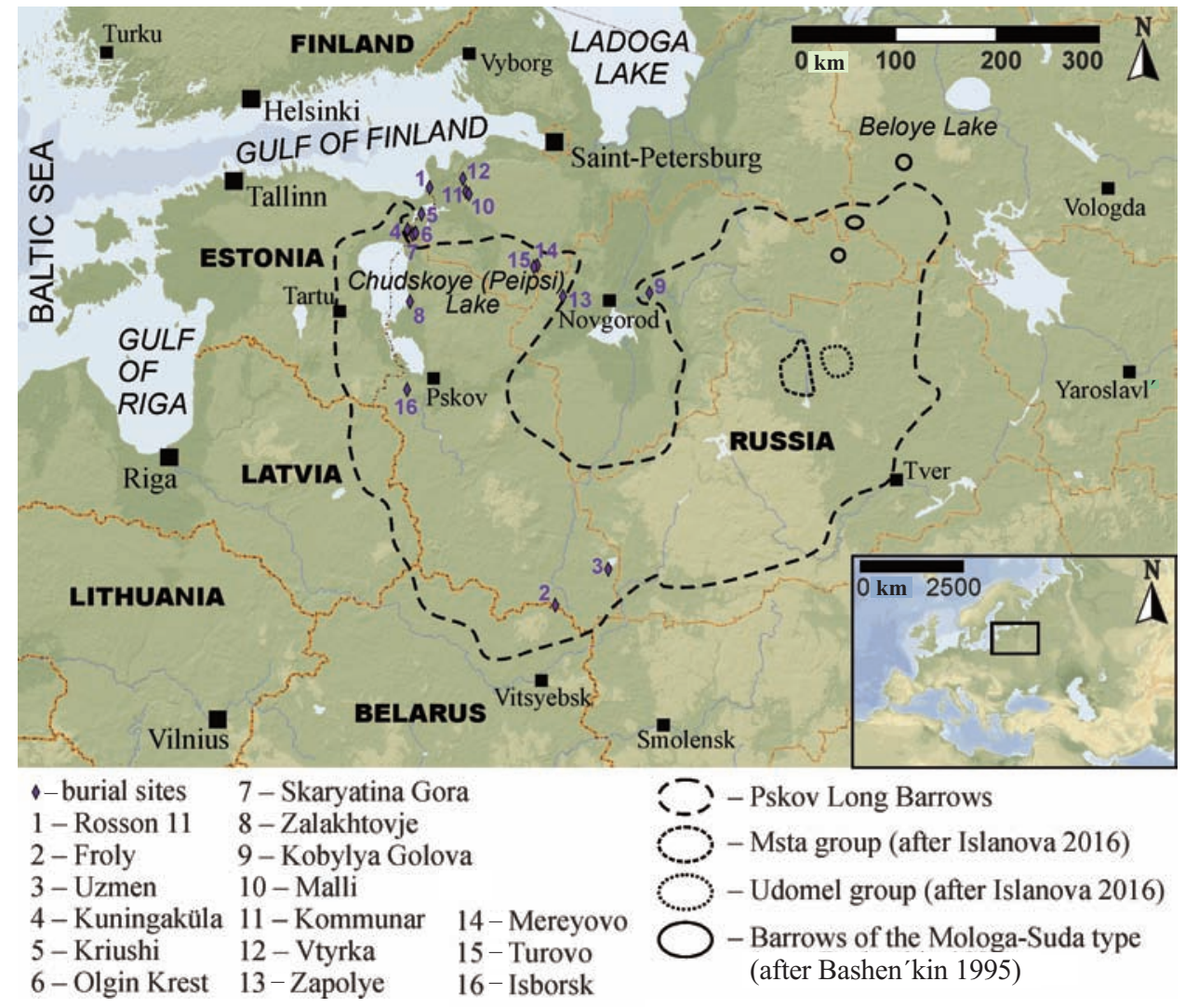

Fig. 1. Map of areas of the so-called Pskov Long Barrows culture of the 1st millennium AD and archaeological sites mentioned in the text. 
Barrows culture (PLB) is the biggest and a relatively well-studied "barrow culture". It was widely spread in the middle and the second half of the 1st millennium AD, in a vast territory from Estonia to the Beloye Lake in Russia, and presumably consisted of several cultural units that were closely related to one another (Sedov 1974; Mikhajlova 2014a, 191-220). There was also a tradition of eastern Lithuanian barrows, just a few of such sites are known in the north-west of Russia (Kazanskij 2014). A rather specific group of barrow cemeteries was defined in the basins of the Mologa and Suda rivers (Bashen'kin 1995, 12 ff.). Burials with stone constructions are known at the western slopes of the Izhora Plateau and to the east of the Pskov Lake. Funerals in such constructions continued from the Roman Iron Age till the Viking Age (e.g. Beletskij 1986; Plotkin 1989; Yakovlev 1999; Kharlashov 2010; Yushkova 2015). Graves with stone structure are typical of Estonia. Most of them date back to the end of the Bronze and beginning of the Iron Age (ca $1200 \mathrm{BC}$ to $450 \mathrm{AD}$ ), but occasionally such structures were also used later (Lang 2007, 147-216; Tvauri 2012, 251).

Cremations buried in pits are especially difficult to detect and therefore have been studied less than other types of burials. Pit graves with cremations are known starting from the first millennium $\mathrm{BC}$, in many places in the eastern Baltic region, therefore, for a long time, this tradition existed in a vast territory, but with certain local and chronological differencies. General descriptions have been made for two studied burial sites in north-west Russia - Uzmen and Froly of the Uzmen-Zaozerye type (3rd-5th c. AD) (Lopatin \& Furas'ev 2007, 51 ff.) - and for several groups of burial grounds from 6th-7th c. AD in the Msta River basin (Islanova 2016, 155 ff.). They have been also found in many parts of Estonia, where, in addition to earlier or later graves, some belong to the Migration Period (Tvauri 2012, 265). Individual cremations buried in pits are known throughout the discussed territory, particularly within PLB tradition, which makes it possible to consider buried cremations as one of the most widespread but the least studied funeral traditions in the north-west of Eastern Europe, in the 1st millennium AD. Therefore, every new discovery of such sites makes an important advance in the topic.

A human cremation Rosson 11 was found in 2013, $1 \mathrm{~km}$ away from the shore of the Gulf of Finland, by the Russian-Estonian border (Fig. 2). Preliminary notes on this find have been published (Mikhajlova et al. 2017). In this paper we present the results of a full-scale research on this notable archaeological site. The landscape situation on the eastern slope of the Kudruküla palaeospit - a relict coastal formation where the site was found - seems to be rather unusual for burials of the discussed time, and may not be considered as related to usual subsistence activity. The site provides an opportunity to reconsider the pattern of using the landscape in the region of the Gulf of Finland in the 1st millennium AD, as well as to develop a regional chronology of the burial tradition.

The history of archaeological studies in the Narva-Luga Klint Bay area is more than a century long (see review in: Kriiska 1996). The research activity has also grown considerably in recent decades, in both Russian and Estonian parts of the region, in a series of national and international scientific projects (Kriiska et al. 2016; Gerasimov et al. 2018). The studies focused mainly on the prehistoric 


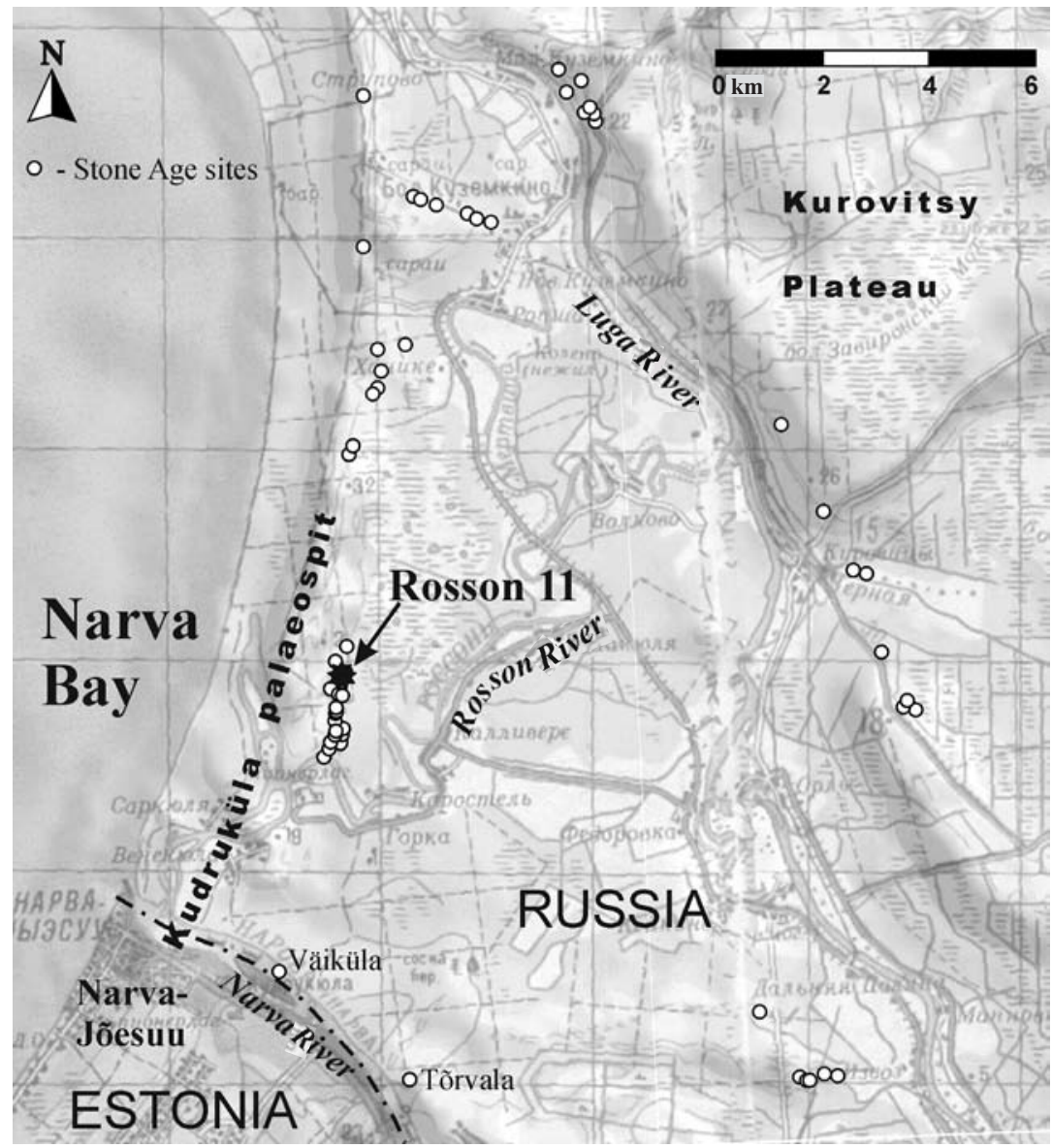

Fig. 2. Map of archaeological sites in the Russian part of the Narva-Luga Klint Bay area.

archaeology. Nevertheless, intensive and systematic field surveys have covered large areas and revealed about a hundred sites from the Stone Age and Early Metal Period.

In the recent decades, palaeogeographical studies in the Narva-Luga Klint Bay brought a great advance in developing the model of shorelines displacement (Rosentau et al. 2013) and coastal formation (Ryabchuk et al. 2019) for the Baltic Sea in the Holocene. These studies allowed to define several generations of palaeospits formed mainly during the Litorina Sea stage (7800-2500 cal. BC; Hang et al. 2019).

The Kudruküla palaeospit is a $25 \mathrm{~km}$ long sandy ridge that roughly stretches from the south to the north, through the Narva-Luga Klint Bay area, along the seacoast. The base of the spit (Fig. 2) is in Estonia, and its point is set against the Kurgalovo Plateau in Russia. Rivers Narva and Rosson cut across the Kudruküla spit. The spit is about $1-1.5 \mathrm{~km}$ wide; its eastern slope falls steep to the Luga River 
valley and to the Kader bog - a former sea lagoon. A chain of dunes up to $15 \mathrm{~m}$ high goes along the central part of the palaeospit, pine forest covers the area.

At the beginning of the 2000s, huge forest fires destroyed large areas of pine trees on the Russian side of the Kudruküla palaeospit. Forestry authorities cleaned the burnt trees away from the fire-damaged areas, and the latter were ploughed for planting new pine trees. The situation caused by the tragic natural disaster brought a unique opportunity for archaeological surveys, as large areas were totally cleared of vegetation (Fig. 3). During several field seasons, intensive and systematic surveys were fruitfully carried out in the area. Most of the sites from the Stone Age to the Early Metal Period in the Narva-Luga interfluve are currently known on the Kudruküla palaeospit. They make several clasters, one of them being a group of sites to the north of the Rosson River. Sixteen archaeological sites were documented there, at the spot of less than $1 \mathrm{sq} . \mathrm{km}$. Most of them are from the Stone Age to the Early Metal Period, but a few finds from later periods were revealed as well.

\section{Rosson 11 archaeological site}

Rosson 11 site was discovered during the 2013 archaeological survey, on the eastern slope of the Kudruküla palaeospit, $1.5 \mathrm{~km}$ north of the Rosson River (Figs 4 and 5). A spot of burnt bones and small pottery fragments (Fig. 6) was found in a forest planting trench at the elevation of $7 \mathrm{~m}$ a.s.l. It was located on the surface of dried former sea bar, closer to the foot of a Litorina Sea terrace 10-11 m high (Fig. 7).

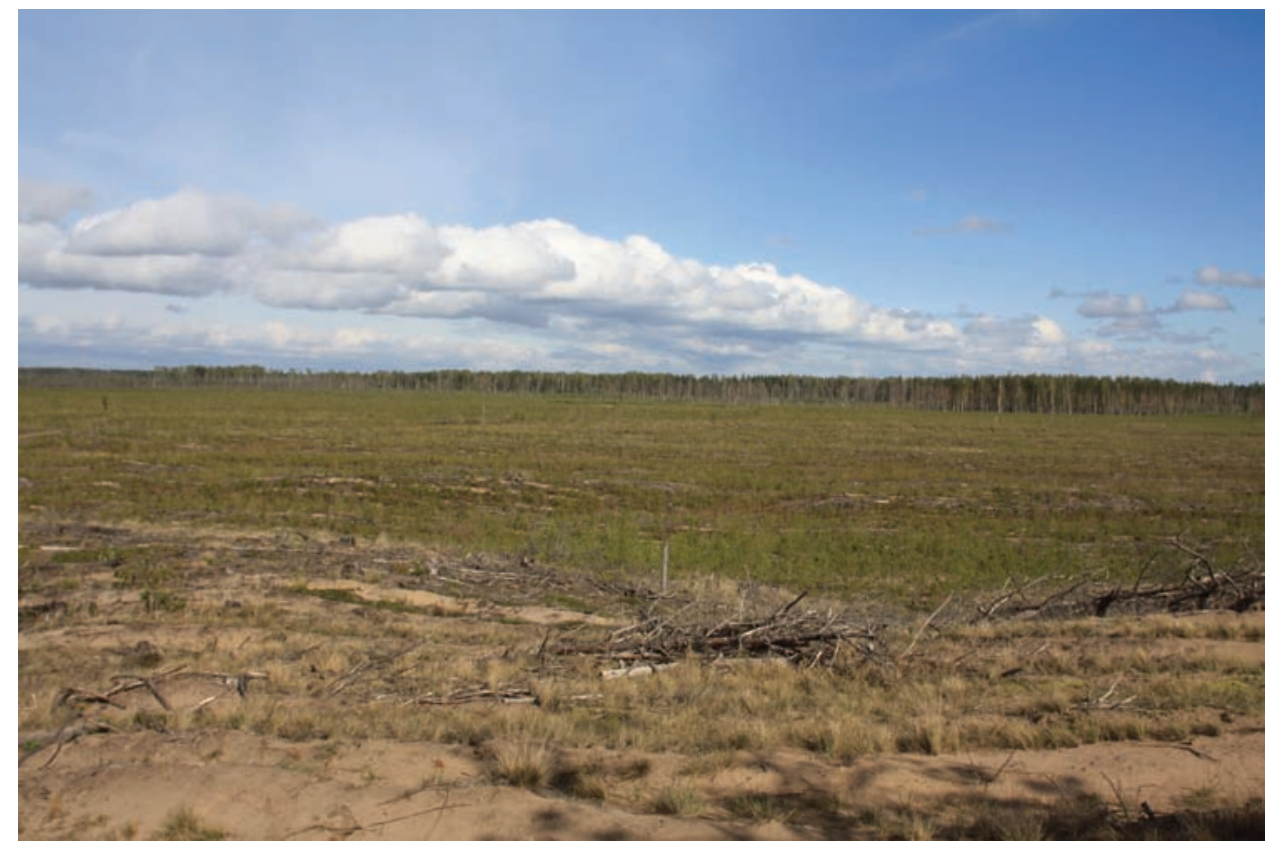

Fig. 3. View from the west to the area north of the Rosson River. Photo by Stanislav Shapiro, 2014. 


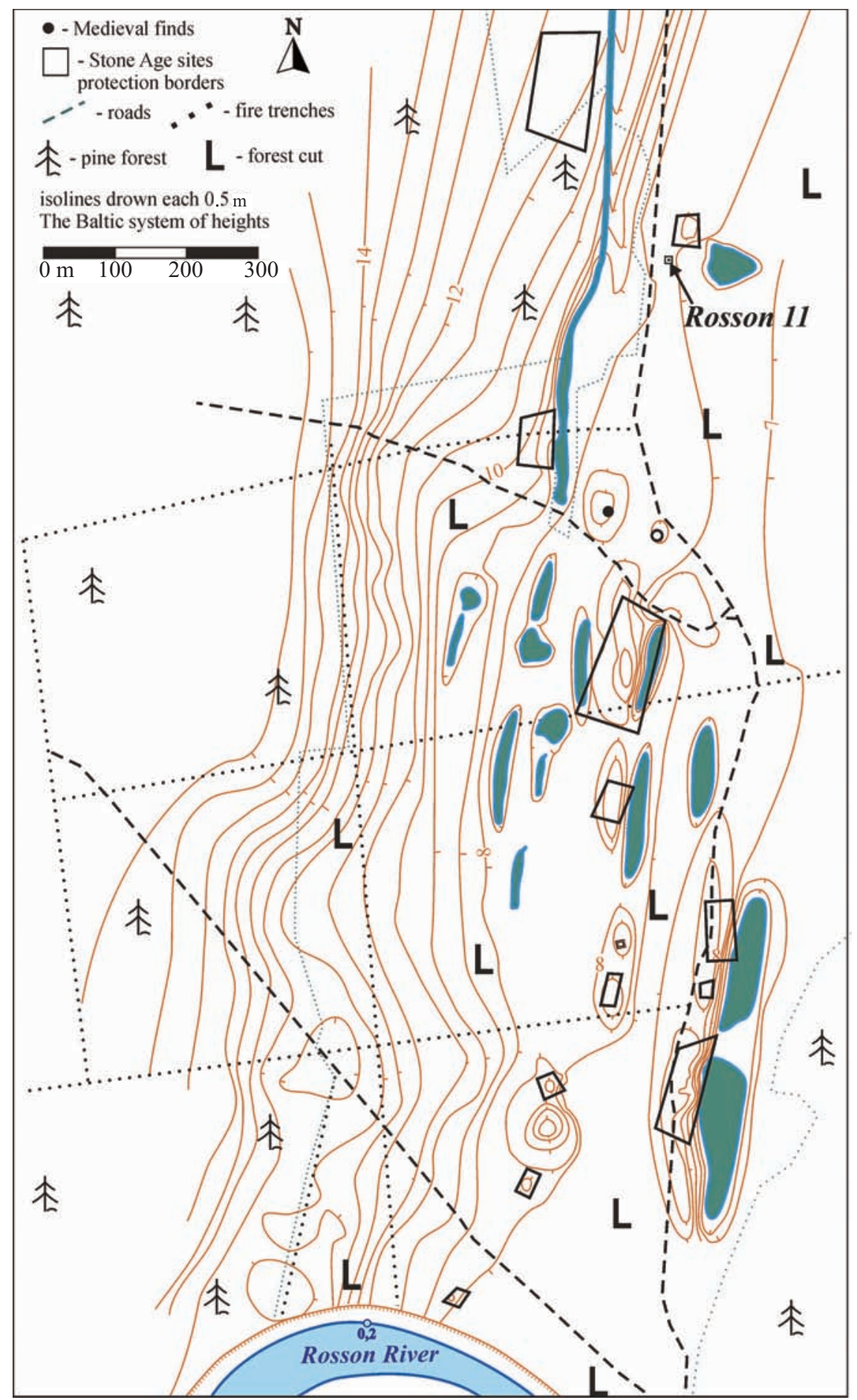

Fig. 4. Map of the group of archaeological sites north of the Rosson River. 


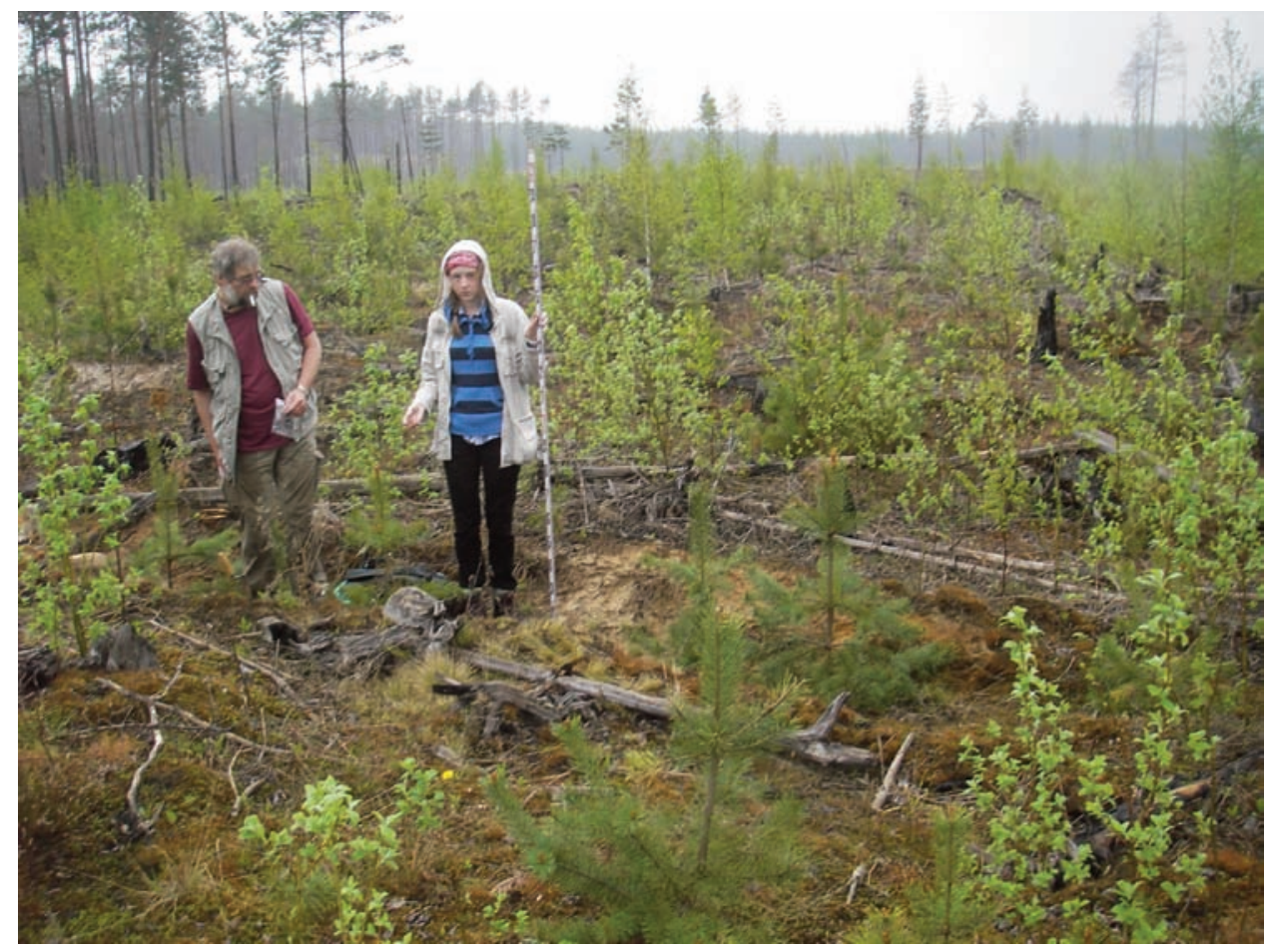

Fig. 5. View of Rosson 11 site from the south. Photo by Dmitriy Gerasimov, 2013.

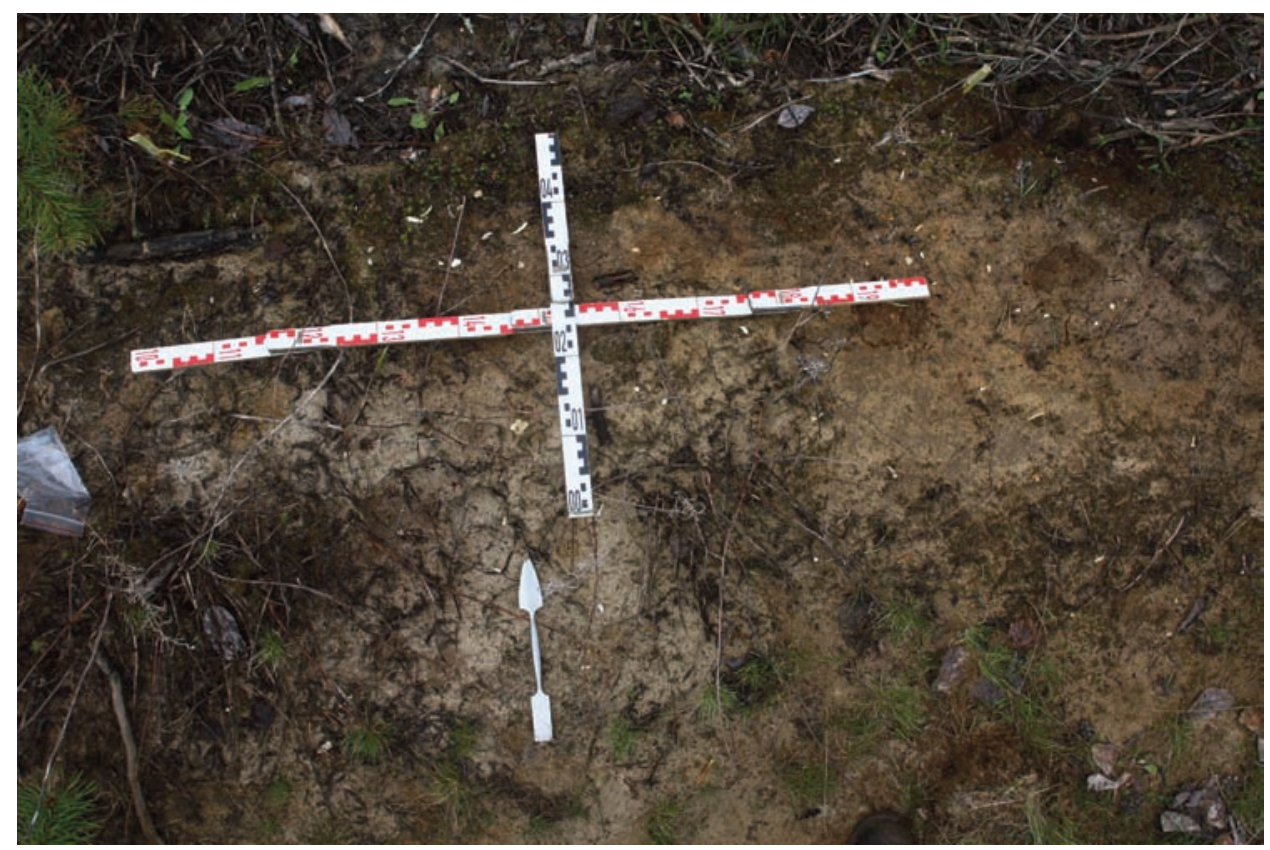

Fig. 6. A spot of burnt bones on Rosson 11 site. View from the south. Photo by Kirill Shmelev, 2013. 


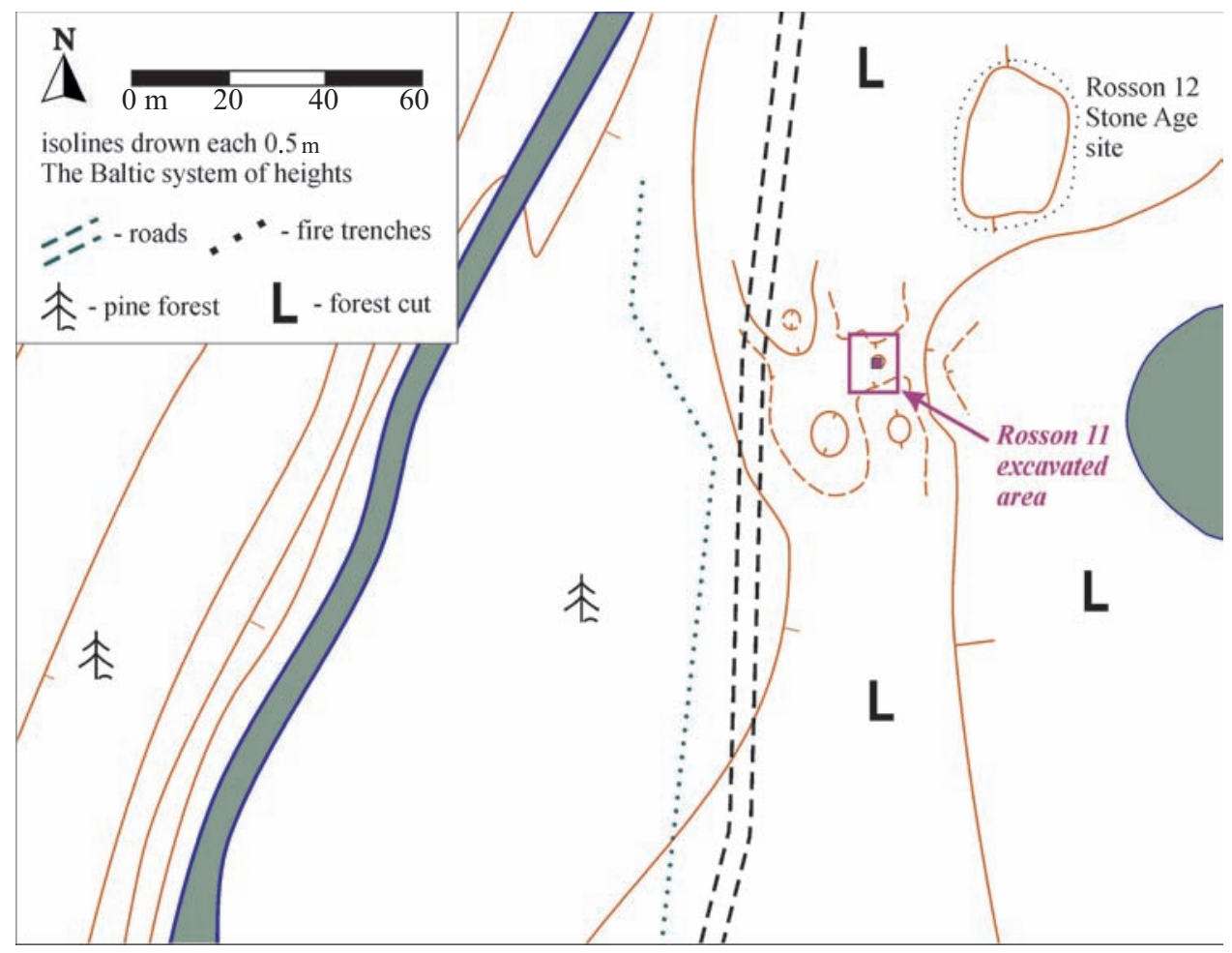

Fig. 7. General plan of Rosson 11 site.

A $2 \times 2 \mathrm{~m}$ excavation unit was investigated on the same place where the concentration of bones had been found (Figs 8 and 9). Archaeological material from the upper layer destroyed by ploughing was collected. After the mixed upper layer was taken out, two more arbitrary horizons were excavated till the bottom of the cultural layer, with detailed documenting of individual finds. All the backdirt was sieved through the screen with $3.5 \mathrm{~mm}$ cell. The lithological profile was studied till the depth of $1.5 \mathrm{~m}$ from the modern surface (Fig. 10).

The mixed layer was 5-20 cm thick. A $10 \mathrm{~cm}$ thick layer of medium-grained reddish sand with high concentration of iron lay below. The central (deepest) part of the forest planting trench destroyed this layer all through. A dark spot $60 \times 60 \mathrm{~cm}$ and $3 \mathrm{~cm}$ thick, with higher organic concentration, was traced in the reddish sand layer (Figs 9 and 11). Its central part was destroyed by the trench. All the documented in situ pottery fragments and pieces of burnt bones were related to the dark spot. The reddish sand layer was underlaid by a $25 \mathrm{~cm}$ thick layer of grey silty small-grained sand with no cultural remains (Fig. 12); below lay light-yellowish medium-grained sorted sand.

Beside the burnt bones, excavations revealed fragments of bronze plate covers with ornament or appendages, melted fragments of a narrow cast bracelet with a longitudinal rib, a fragment of a smooth plate iron artefact (Fig. 13), and four small 


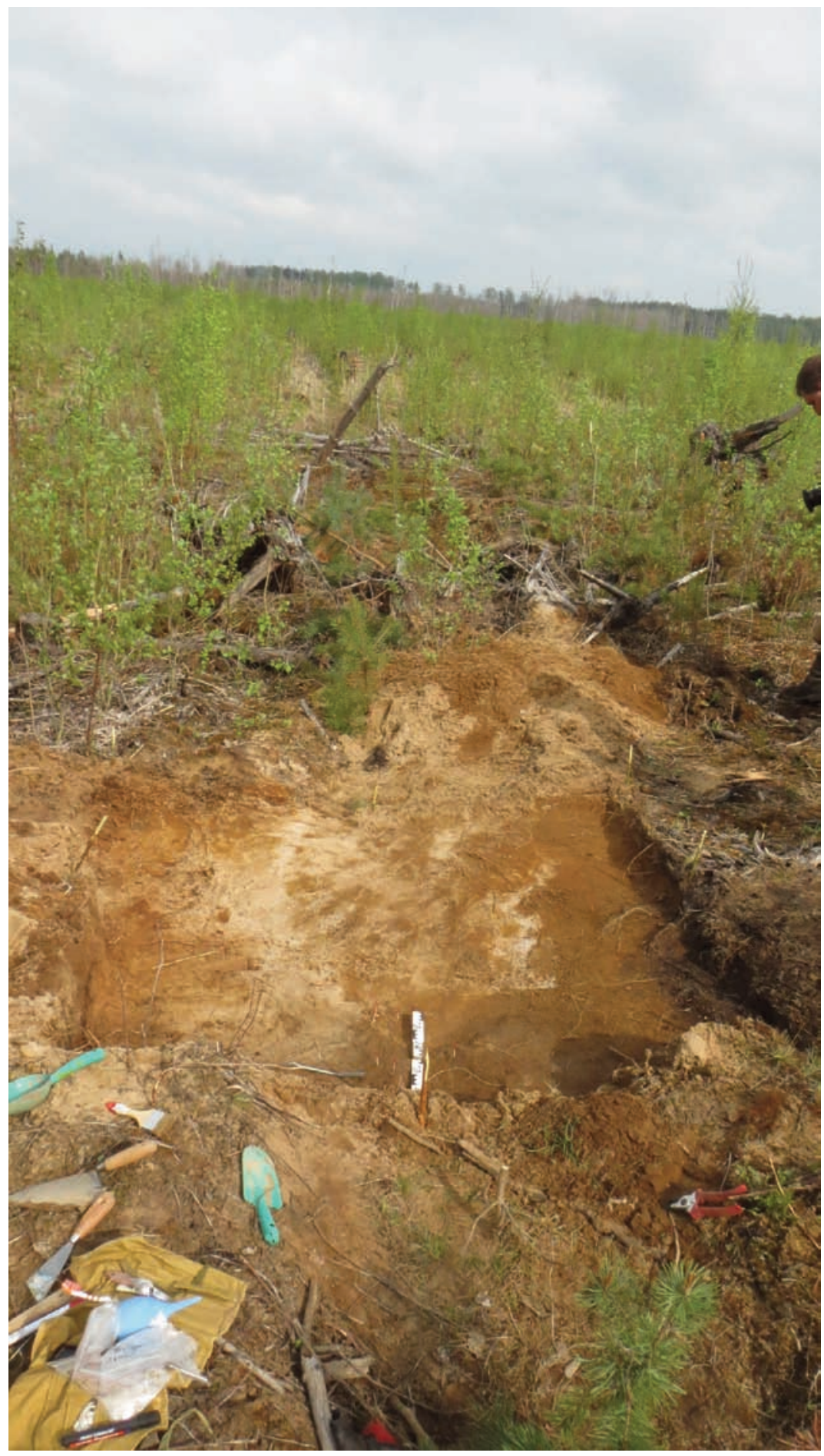

Fig. 8. View from the west to the excavation unit on Rosson 11. Photo by Aivar Kriiska, 2013. 


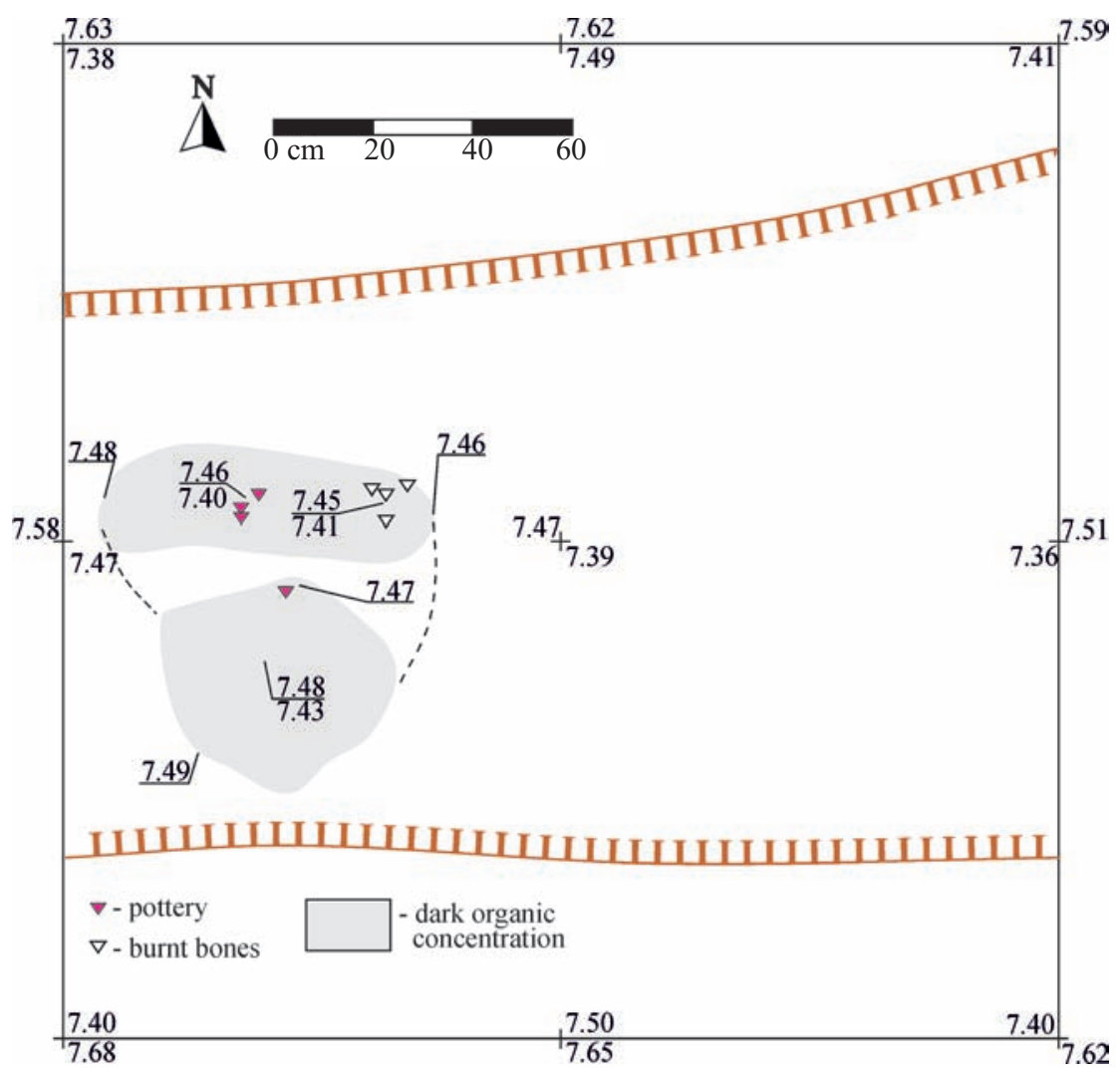

Fig. 9. Rosson 11. Plan of the excavation unit.

fragments of hand-built pottery. Spatial analysis of the pattern of the finds has shown that the compact concentration was pooled by a plough along the trench.

The area around the spot of finds was systematically searched with metal detector that revealed several anomalies in the surroundings. In 2015, an area of 120 sq. m was excavated around the 2013 unit. No more traces of archaeological remains were found, only a piece of bronze blade artefact with an ornament was found next to the border of the 2013 unit (Fig. 14).

A fragment of burnt bone was analysed in the 14CHORNO Centre at Queen's University Belfast. The obtained date was calibrated using OxCal 4.3.2 program (Bronk Ramsey 2017) with IntCal 13 atmospheric curve (Reimer et al. 2013).

\section{Attribution of the burial context}

Judging by spatial distribution and assemblage of the finds, Rosson 11 archaeological site represents a single burial, but not a part of a burial ground. No cultural remains were revealed in the excavated area around the cremation, although 


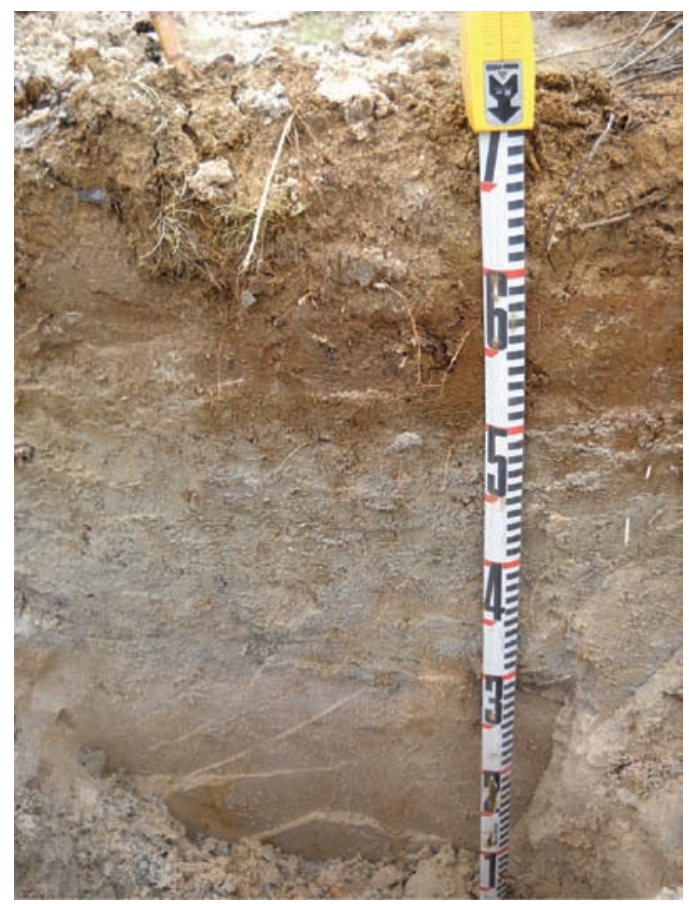

Fig. 10. Rosson 11. Geological profile at the western wall of the excavation unit. Photo by Dmitriy Gerasimov, 2013.

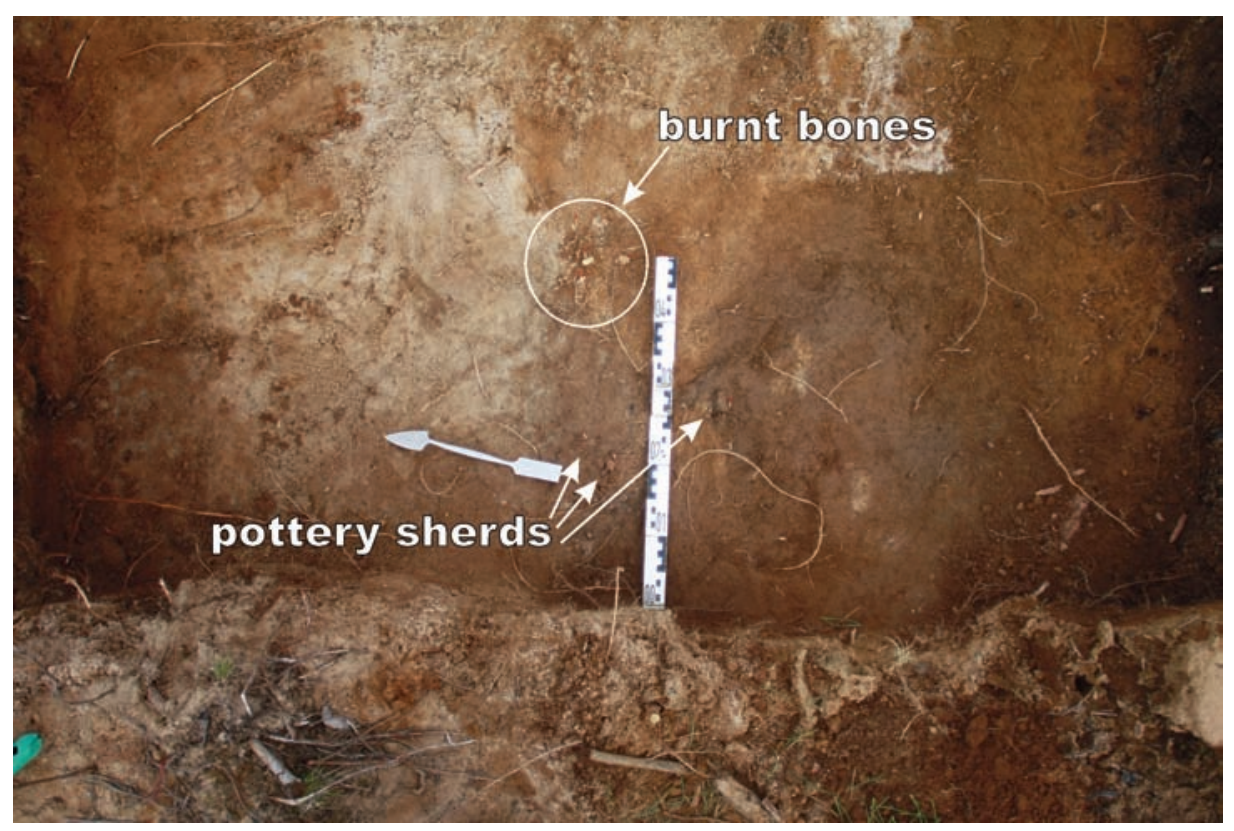

Fig. 11. Rosson 11. Dark spot with organic concentration. View from the west. Photo by Kirill Shmelev, 2013. 


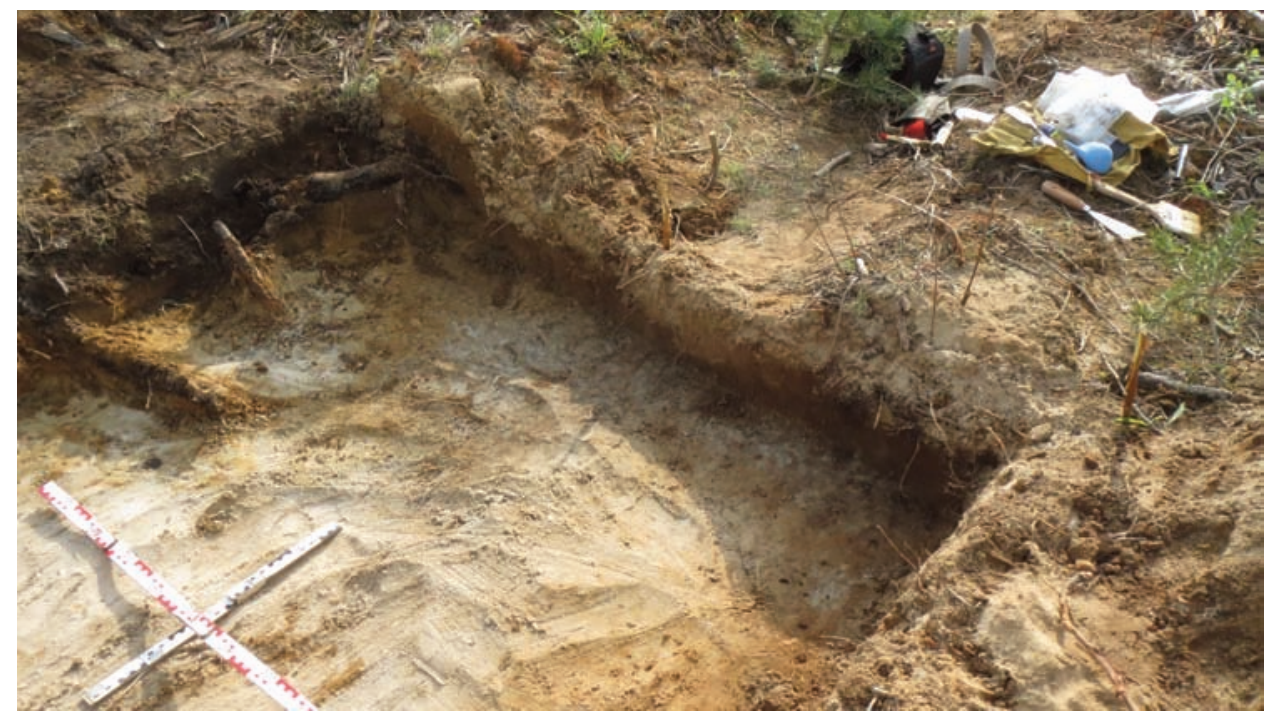

Fig. 12. Rosson 11. Bottom of the cultural layer. View from the north-east. Photo by Aivar Kriiska, 2013.

large parts of surface between trenches were not disturbed by ploughing. As there were no traces of a fireplace, the cremation might have been performed at a distance, and the remains placed in a pot and buried in a small pit.

Skeletal remains were represented by small fragments of tubular and (less frequently) flat bones. The anatomical identification of bones was impossible in most cases. There were small fragments of the cranial vault, a fragment of the occipital bone with a part of the cruciform eminence, a fragment of the metacarpal bone, fragments of the roots of the teeth, fragments of the forearm bones, distal epiphysis of the hand (or foot) phalanx, a fragment of the articular process of the vertebra, and a fragment of the spinous process of the vertebra (probably thoracic). The presence of animal bones among the remains cannot be ruled out, however there are no morphological (visually detectable) traits to confirm this assumption.

The remains belonged to an individual over 14 years old. The head of the metacarpal bone is completely fused with the body. There is no evidence of articular surfaces degeneration, preserved suture edge of cranial vault bone is clear, it can be expected that the buried person was not old. Presumably, the age was between 15 and 45 years. The information is insufficient for reliable sex determination. Sex can be defined as probably female. The only argument to sustain this assumption is that the external occipital protuberance is unexpressed.

Some bone fragments were deformed. Most of the fragments had longitudinal fractures, however, spiral and less often curved deep fractures were recorded on the fragments of some tubular bones. Researchers associate the latter traits with cremation of bodies with preserved soft tissues or defleshed "fresh" bones. There is growing evidence that neither deformations, nor curved or thumbnail fractures, 

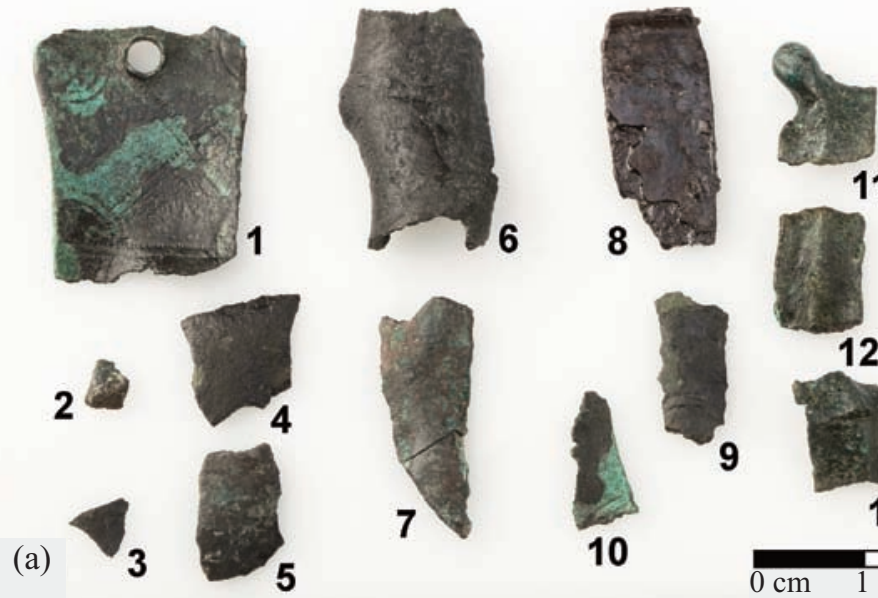

11
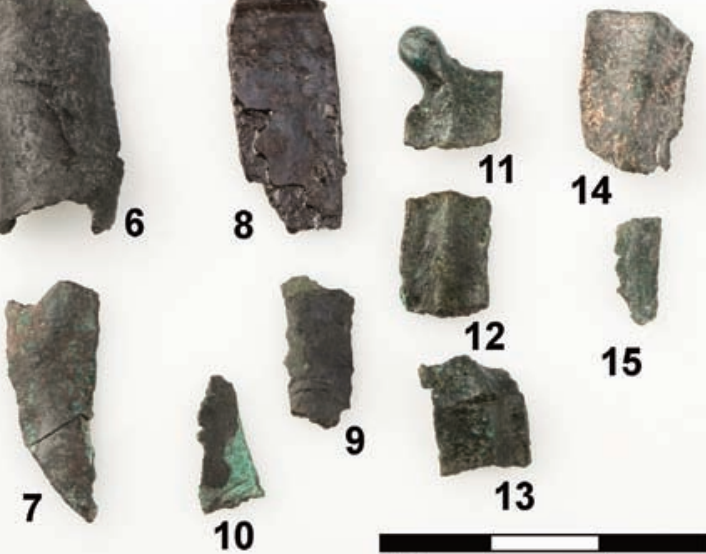

15
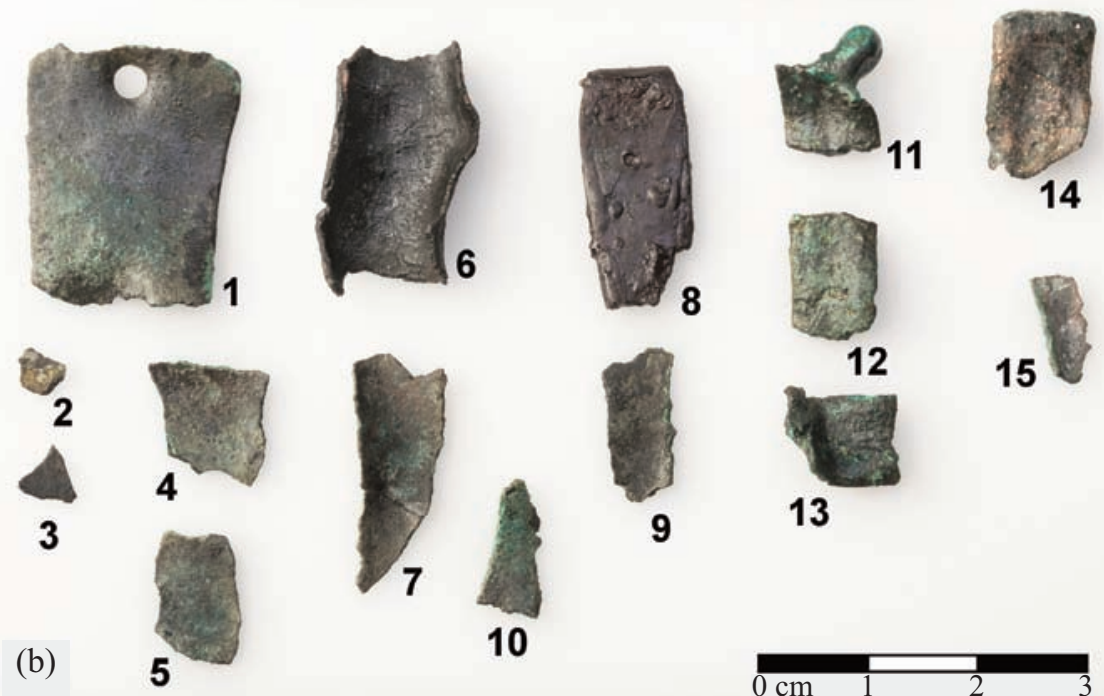

14

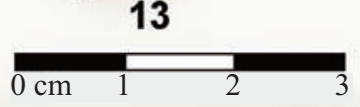

Fig. 13. Rosson 11. Metal artefacts. 1 - bronze ornamented plate cover, 2-7, 9-10, 15 - bronze plate fragments, 8 - iron plate fragment, 11-13 - bronze bracelet with longitudinal rib, 14 - copper plate fragment.

nor a combination of those features, allow to determine the presence or absence of soft tissues on the bones during the cremation or even to separate fresh bones from dry ones with $100 \%$ confidence (the discussion history can be found, for example, in Larsson 2009). Statistically, curved fractures and deformations of bones are more common during the cremation of bodies (Gonçalves et al. 2015).

The maximum temperature of combustion was above $600-700{ }^{\circ} \mathrm{C}$. The external and internal sides of the diaphysis of the tubular bones, roots of the teeth are pale gray or white in colour. The total mass of skeletal remains is $87.5 \mathrm{~g}$. According to 


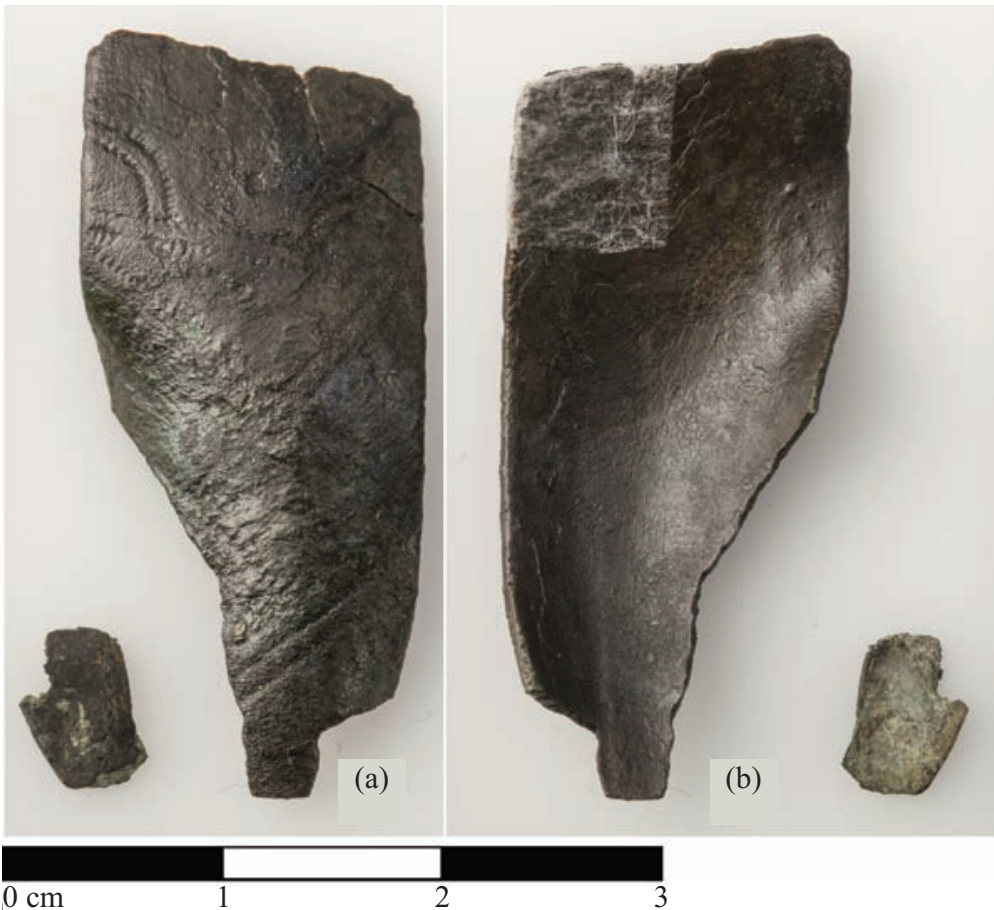

Fig. 14. Rosson 11. Ornamented bronze plate fragment.

numerous observations made in modern crematoriums, the average mass of cremated remains of an adult is from 1 to $3 \mathrm{~kg}$; the remains of men tend to weigh more than those of women (McKinley 1993; Bohnert et al. 1998; Chirachariyavej et al. 2007). The weight of bones from archaeological sites is almost always less than expected, even when buried in urns. This is partly due to the unintentional loss of remains during the transfer of bones from fireplace to the burial site and their fragmentation as a consequence of post-depositional processes. However, huge discrepancies between observed and expected weights of the remains were apparently due to the fact that those who participated in the funeral did not intend to bury all the cremated bones.

There are very few artefacts from Rosson 11. All the pottery fragments from the surface and excavations were very small and typologically unexpressive. This was a hand-built pottery with gravel admixture in clay mass. Fragments of recognizable morphology were from the bottom part of the vessel - probably of an urn. Beside the pottery, there were several small fragments of metal artefacts found in the burial (Fig. 13). There was a fragment of an iron plate with a bent edge (Fig. 13: 8a-b) and fragments of ornaments of copper alloy (here we call them bronze, although the composition of metals was not analysed) with signs of burning. Among the bronze artefacts, it was possible to define small fragments of ornamented plates (Figs 14 and 15: 1-2) and of a narrow cast bracelet with a longitudinal rib (Fig. 15:3-5). 


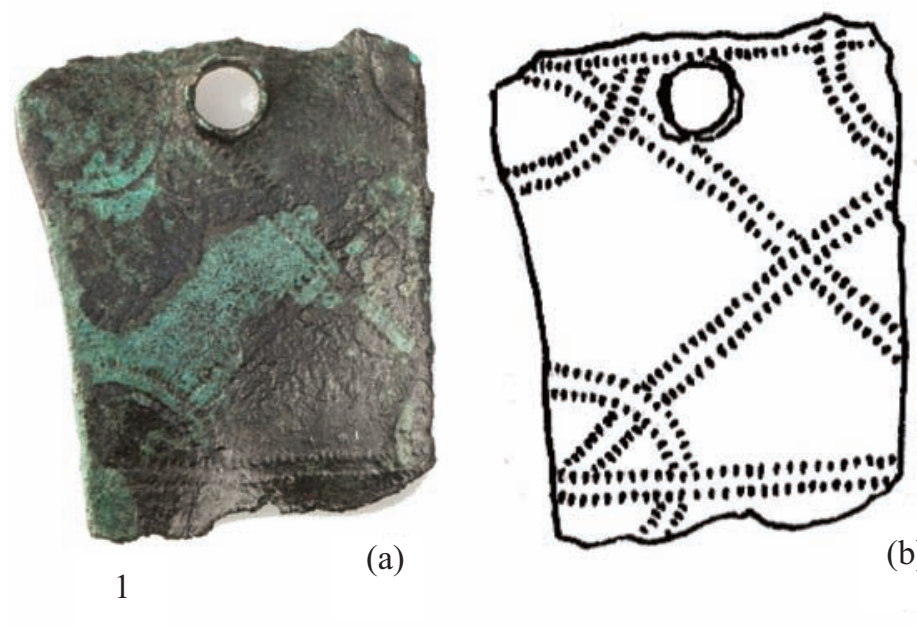

(b)

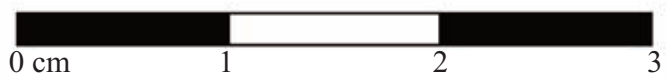

2

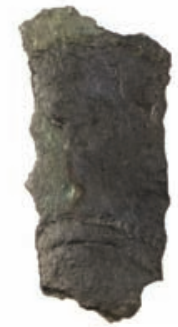

(a)

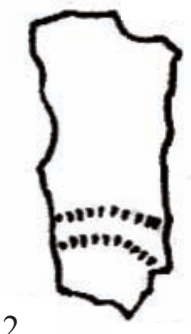

(b)
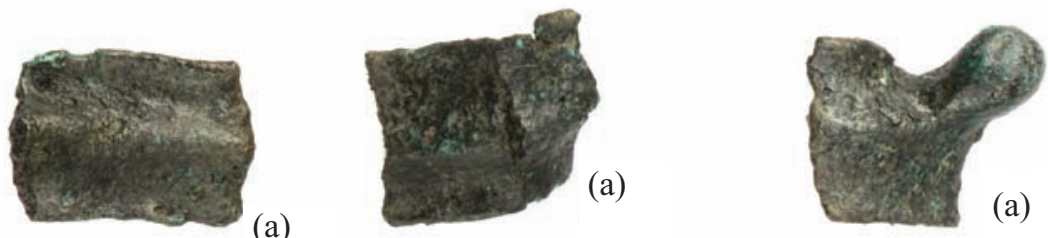

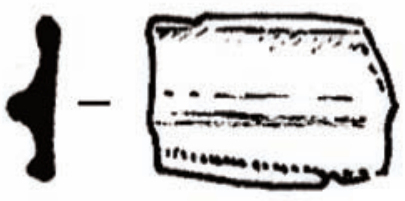

3 (b)

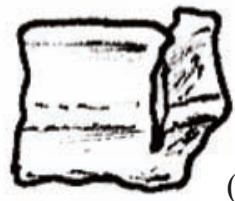

(b)

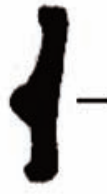

4

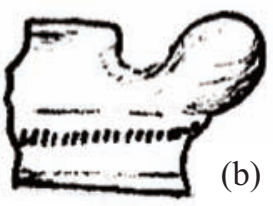

5

Fig. 15. Rosson 11. Ornamented bronze artefacts. 1-2 - ornamented plate covers, 3-5 - fragments of bracelet with longitudinal rib.

Different types of covers and clips made of metal plates were well presented in the whole Europe, including Baltic regions. From the Roman Iron Age, they were used in belt, headband, and hair plait furniture, as covers on bridle, saddles, or wooden dishes, etc.

There is no general compilation on metal plate assemblages of the 1st millennium $\mathrm{AD}$ yet, but information on this category of artefacts is available in many regional observations (e.g. Shcheglova 2004; Ciglis 2006; Myts et al. 2006, 136, 157; Krenke 2011, 71 ff., 89 ff.; Leshchinskaya 2012, 130; Khomiakova 2015, 25 ff.; Akhmedov \& Gavrilov 2017). There is a rather big hole with uneven bent 
edges on one of the fragments of the ornamented bronze plate from Rosson 11 (Fig. 15: 1). It was very probably attached with a rivet to a lather belt or to a hard base (for example to a wooden box).

The fragments of a bronze bracelet from Rosson 11 represent a much more typologically pronounced item. The narrow (ca $8 \mathrm{~mm}$ ) cast plate bracelet with a longitudinal rib was ornamented with shallow pits along the rib and edges. This item allows to confidently date the whole context of Rosson 11 within the middle and the third quarter of the 1st millennium $\mathrm{AD}$, based on typological parallels. Generally, plate bracelets with longitudinal ribs along edges or the axis are known among the antiquities of the Baltic basin since the Roman Iron Age and till the Viking Age. Nevertheless, narrow cast pieces make a rather compact group among the antiquities of the north-west of Eastern Europe; the easternmost finds were defined to the east of the Ilmen Lake (Gorodok-na-Mayate, Kobylya Golova). The geographically closest sites with artefacts similar to the Rosson 11 bracelet are located on the western slope of the Izhora Plateau (Malli, Kommunar, Vtyrka). Finds from the long barrows in the Luga River basin (Meryovo 3, Turovo VI), in the northwest Belarus (Pagoscha), and in the cultural layer of the Izborsk (Truvorovo) hillfort (Figs 1 and 16) are also worth mentioning here. Sealed contexts with such bracelets can be dated within 5 th-8th c. AD, in several cases even more narrow timeframes can be considered (for details, see Mikhajlova 2015a).

In the middle and the third quarter of the 1st millennium AD, in the north-west of Eastern Europe, bracelets of all kinds were most likely decorations worn by women. The studied PLB materials give good evidence in favour of this assumption, as quite many burial remains were analysed by physical anthropologists (Mikhajlova 2015 b). Sparse materials from burials of other traditions do not contradict such attribution.

AMS date obtained from a burnt bone fragment gave the interval of 420-560 cal AD (1561 \pm 27 BP, UBA-29063).

\section{Discussion}

The Rosson 11 burial differs from burials with stone constructions known in Estonia and Izhora Plateau, as well as from PLB and presumably eastern Lithuanian barrows located to the south of the lower course of the Luga River. Nevertheless, it does not look completely alien in the general funeral context of the Migration Period. Strewn and buried cremations of the middle and the second part of the 1st millennium AD that were discovered during the two latest decades are numerous enough for us to claim that cremations were among the main types of funeral practices from the Late Roman Iron Age to the Viking Age. The tradition to place the remains of cremation aside in a shallow pit or to strew them on surface was one of the most spread funeral traditions in the forest zone of the Eastern Europe and persisted up to the early 2nd millennium AD (Mikhajlova 2014b, 332). 


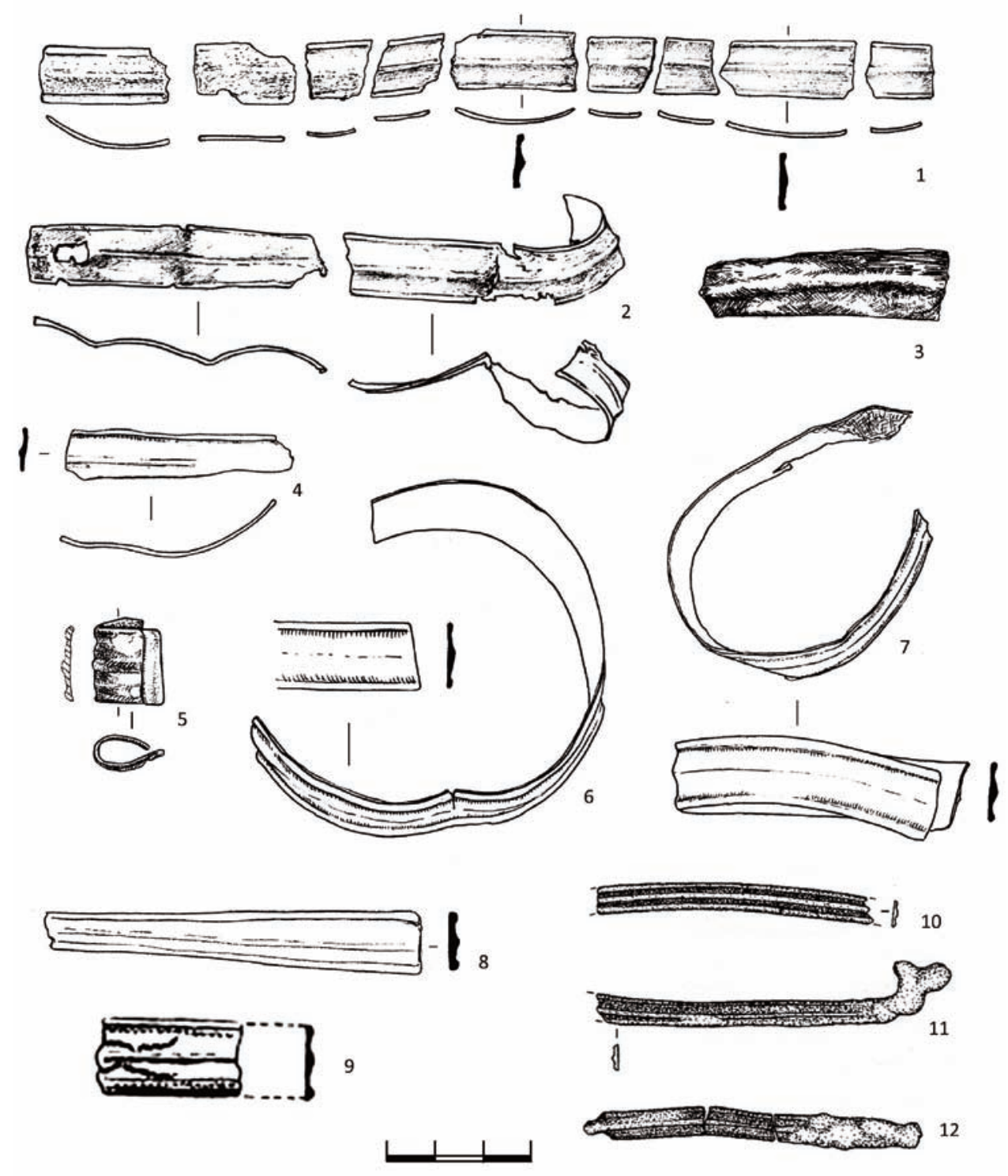

Fig. 16. Closest analogies to the Rosson 11 bracelet. 1, 2 - Mereyovo 3 (after Mikhajlova 2015a, fig. 3: 5-6), 3 - Izborsk (Truvorovo hillfort) (after Sedov 2007, fig. 75), 4 - Kommunar (after Mikhajlova 2015a, fig. 5: 1), 5 - Gorodok-na-Mayate (after Eremeev \& Dzyuba 2010, fig. 104), 6, 7 - Turovo 6 (after Mikhajlova 2015a, fig. 4: 6), 8-Vtyrka (Pillovo) hillfort (after Mikhajlova 2015a, fig. 5: 5), 9 - Kobylya Golova (after Orlov 1968, fig. 4), 10-12 - Pagoscha (after Plavinski 2017, fig. 27). 1-8, 10-12 - copper alloy, 9 - silver (?). 
The grave fields with cremations from the banks of the Narva River (Kuningaküla, Olgin Krest, Kriushi, Skaryatina Gora) are the closest geographically to the Rosson River. On those sites, buried cremations were accompanied by burnt weapon items stuck into the ground and can be confidently dated from the 9th-11th c. (Ligi 1993, 23 f.). Similar burials of the same period were studied in several locations in Estonia and in the Zalakhtovye burial ground at the eastern shore of the Peipsi (Chudskoye) Lake (Khvoshchinskaya 2004, 26 ff.; Tvauri 2012, 264 ff.). However, the older burials with cremations, which are synchronous to the Rosson 11 site, are also well known in the north-west of Eastern Europe. Burials in shallow pits make an important part of the PLB funeral tradition. There are occasional burials in pits within groups of barrows, as well as grave fields with burials of this type only. One of such grave fields is known in the Kobylya Golova archaeological complex, next to the dwelling site, where a fragment of a bracelet with a longitudinal rib was found (Orlov 1968, 166 f.). Two burial grounds with cremations from the middle and the third quarter of the 1st millennium $\mathrm{AD}$ were recently studied in the western part of the Izhora Plateau at the Solka River, the right tributary of the Luga River. In the Malli burial ground, scattered remains of cremations accompanied by numerous artefacts of the 5th-8th c. AD overlaid burials with stone frames (tarand) of the Roman Iron Age. Among the metal finds from the upper cultural layer, there were costume furniture and ornaments of different types (buckles, fibulas, bracelets), as well as arm and weapon items (swords, spearheads, shield umbos). Unfortunately, the arm and weapon items were mainly obtained with no proper documentation, in the course of illegal excavations. The finds from Malli are of wide-spread European types, although some direct analogues can be found in Estonia or Finland (Yushkova 2015, 195). The Kommunar burial ground on the left bank of the Solka River is still understudied. It seems to be similar to the Malli burial ground in the details of burial rites, as well as in the typology of burial goods (Mikhajlova \& Fedorov 2011).

The location of the Rosson 11 burial is untypical. The majority of known burials from the Migration Period in the north-west of Eastern Europe (including all the mentioned above) are situated on small heights or hills, on tops of fluvial-glacial eskers, high steep river banks. The Rosson 11 burial is located in a plain and marshy area. In this respect, the burial grounds found and studied to the east, in the Mologa-Sheksna lowland, are of interest. At the end of the Ice Age, the lowland was covered by the huge Mologa-Sheksna palaeolake. The geomorphology of the landscape was formed by water and displays certain similarities to the Narva-Luga interfluve. There are several burial fields with cremations placed in pits or strewn on the ground surface. These burials are related to the development of local traditions. They are dated in wide frames - from the Early Iron Age to the end of the 1st millennium AD (Bashen'kin 1995, 7 ff.; Kudryashov 2014). The burials in the Mologa-Sheksna lowland are located on even river terraces or on poorly pronounced small heights (lower than $1 \mathrm{~m}$ ) - such locations remind of the context where the Rosson 11 burial was found.

The Zapolye burial ground in the upper course of the Luga River should be also mentioned in this connection. At the end of the 1 st millennium $\mathrm{AD}$, it was 
surmounted with a high mound (sopka). Six cremations were revealed under the mound: five were buried in pits, one more was documented as a concentration of burnt bones. Two burials contained melted fragments of bronze artefacts. Three radiocarbon dates from the site gave the time interval of the 4th-5th c. turn to the middle of the 7th c. AD. This site is geographically rather close to Rosson 11; its location on a low river terrace is also noteworthy (Platonova 1996; 2002, 195).

\section{Conclusions}

The modern methodology of field survey aimed at revealing medieval funeral contexts in the north-west of Eastern Europe is focused primarily on surveying moraine hills and ridges, basic banks of water bodies or high terraces covered with pine trees - the landscapes where most of the known groups of barrows are located. A single cremation of a woman (?) in the Rosson 11 site dates from 5th-6th c. AD provides an example of possible use of another kind of landscape. This opens new perspectives in discovering antiquities from the Migration Period in the region, but may also be considered as evidence of exploration of the coastal landscape by the population of Ingria in the middle of the 1st millennium AD.

\section{Acknowledgements}

Metal archaeological finds from Rosson 11 were cleaned and conserved by Inna L. Marmer (MAE RAS). Pictures of artefacts were taken by Stanislav B. Shapiro (MAE RAS). This paper has been supported by the research projects "The Old and the New World - Formation and development of ancient societies and populations", "Natural sciences methods in studies of archaeological and anthropological materials" (Museum of Anthropology and Ethnography /Kunstkamera/ Russian Academy of Sciences); "Prehistoric inhabitation of Peipsi lowland and protection of cultural heritage" (Institute of History and Archaeology of the University of Tartu). The authors are grateful to the two referees for their comments on the manuscript. The publication costs of this article were covered by the Estonian Academy of Sciences, the Institute of History and Archaeology at the University of Tartu, and the Institute of History, Archaeology and Art History of Tallinn University.

\section{References}

Akhmedov, I. \& Gavrilov, А. 2017. = Ахмедов И. Р. \& Гаврилов А. П. Находки матриц для изготовления деталей геральдических поясов в древностях рязано-окских финнов. - Stratum Plus, 5, 17-39.

Bashen'kin, А. 1995. = Башенькин А. Н. Культурно-исторические процессы в МологоШекснинском междуречье в конце I тыс. до н.э. - I тыс. н.э. - Проблемы истории Северо-Запада 
Руси (Славяно-русские древности). Еds И. В. Дубова \& И. Я. Фроянова. Изд-во СанктПетербургского государственного университета, Санкт-Петербург, 3-29.

Beletskij, S. 1986. = Белецкий C. В. Курган у деревни Романово под Псковом. - Советская археология, 3, 174-184.

Bohnert, M., Rost, T. \& Pollak, S. 1998. The degree of destruction of human bodies in relation to the duration of the fire. - Forensic Science International, 95, 11-21.

Bronk Ramsey, C. 2017. OxCal 4.3 manual. https://c14.arch.ox.ac.uk/oxcal/OxCal.html, Accessed date: 1 . August 2020.

Chirachariyavej, T., Limburanasombat, S. \& Tiensuwan, M. 2007. The relationship between bone and ash weight to body weight and body length of Thai corpses in Bangkok and central part of Thailand after cremation. - Journal of Medical Association of Thailand, 90: 9, 1872-1878.

Ciglis, J. 2006. V-IX amžiaus diržų sagtys Rytų Latvijoje. - Archaeologia Lituana, 7, 156-170.

Eremeev, I. \& Dzyuba, О. 2010. = Еремеев И. И. \& Дзюба О. Ф. Очерки исторической географии лесной части Пути из варяг в греки. Археологические и палеогеографические исследования между Западной Двиной и озером Ильмень. Нестор-История, Санкт-Петербург, 2010.

Gerasimov, D., Kriiska, A., Nordqvist, K. \& Kholkina, M. 2018. Cross-Gulf cooperation in the Stone Age study: new results, continuing projects and research perspectives. - International Scientific Forum "Gulf of Finland - Natural Dynamics and Anthropogenic Impact", Devoted to 50th Anniversary of Trilateral Gulf of Finland Co-operation. Abstracts (17-18 October 2018, St. Petersburg, Russia). VSEGEI Press, Санкт-Петербург, 31-34.

Gonçalves, D., Cunha, E. \& Thompson, T. J. U. 2015. Estimation of the pre-burning condition of human remains in forensic contexts. - International Journal of Legal Medicine, 129, 1137-1143.

Hang, T., Veski, S., Heinsalu, A., Vassiljev, J., Seppä, H., Poska, A. \& Kriiska, A. 2019. Eesti Holotseeni stratigraafiline skeem. Eesti Stratigraafia Komisjon. https://doi.org/10.15152/GEO.479

Islanova, I. 2016. = Исланова И. В. Раннесредневековые группы памятников на северо-западе Восточной Европы. - Раннесредневековые древности лесной зоны Восточной Европы (V-VII вв.). Eds A. М. Обломский \& И. В. Исланова. (Раннеславянский мир, 17.) Институт археологии РАН, Москва, 136-220.

Kazanskij, М. 2014. = Казанский М. М. Удила эпохи великого переселения народов из погребения в Доложском погосте. - Stratum Plus, 5, 119-127.

Kharlashov, В. 2010. = Харлашов Б. Н. Курганы с каменными конструкциями в округе Пскова и Изборска (к постановке проблемы). - Краеугольный камень. Археология, история, искусство, культура России и сопредельных стран. 80-летию со дня рождения А. Н. Кирпичникова посвящается, II. Eds E. Н. Носов \& С. В. Белецкий. Ломоносовъ, Москва, 459-468.

Khomiakova, O. 2015. Disc brooches of Dollkeim-Kovrovo Culture. The question of the origin of ornaments in the southeast Baltic in the first centuries AD. - Archaeologia Baltica, 21-22, 14-39.

Khvoshchinskaya, N. 2004. = Хвощинская Н. В. Финны на западе Новгородской земли (По материалам могильника Залахтовье). Дмитрий Буланин, Санкт-Петербург.

Krenke, N. 2011. = Кренке Н. А. Дьяково городище: Культура населения бассейна Москвыреки в I тыс. до н.э. - I тыс. н.э. Институт археологии РАН, Москва.

Kriiska, A. 1996. Stone Age settlements in the lower reaches of the Narva River, north-eastern Estonia - Coastal Estonia. Recent Advances in Environmental and Cultural History. Eds T. Hackens, S. Hicks, V. Lang, U. Miller \& L. Saarse. (PACT, 51.) Rixensart, 359-369.

Kriiska, A., Gerasimov, D. V., Nordqvist, K., Lisitsyn, S. N., Sandell, S. \& Kholkina, M. A. 2016. Stone Age research in the Narva-Luga klint bay area in 2005-2014. - New Sites, New Methods. Proceedings of the Finnish-Russian Archaeological Symposium, Helsinki, 19-21 November, 2014. (Iskos, 21.) Suomen Muinaismuistoyhdistys, Vaasa, 92-106.

Kudryashov, А. 2014. = Кудряшов А. В. Белозерская весь: современный взгляд. - Русь в IXXII веках: общество, государство, культура. Еds Н. А. Макаров \& А. Е. Леонтьев. Древности Севера, Москва, Вологда, 299-311. 
Lang, V. 2007. The Bronze and Early Iron Ages in Estonia. (Estonian Archaeology, 3.) Tartu University Press, Tartu.

Larsson, A. M. 2009. Breaking and Making Bodies and Pots. Material and Ritual Practices in Sweden in the Third Millennium BC. (Aun, 40.) Uppsala University, Uppsala.

Leshchinskaya, N. 2012. = Лещинская Н. А. Хронология и периодизация пьяноборских могиьников $\mathrm{I}-\mathrm{V}$ вв. н.э. бассейна р. Вятки. - Древности Прикамья эпохи железа (VI в. до н.э. - XV в. н.э.): хронологическая атрибуция. Сборник статьей. Ed. Р. Д. Голдина. (Материалы и исследования Камско-Вятской археологической экспедиции, 25.) Удмуртский университет, Ижевск, 124-163.

Ligi, P. 1993. Vadjapärased kalmed Kirde-Eestis (9.-16. sajand). - Vadjapärased kalmed Kirde-Eestis (9.-16. sajandil). Ed. V. Lang. (MT, 2.) Tallinn, 7-152.

Lopatin, N. \& Furas'ev, А. 2007. = Лопатин Н. В. \& Фурасьев А. Г. Северные рубежи раннеславянского мира в III-V вв. н.э. (Раннеславянский мир. Археология славян и их соседей, 8.) Институт археологии РАН, Москва.

McKinley, J. 1993. Bone fragment size and weights of bone from modern British cremations and the implications for the interpretation of archaeological cremations. - International Journal of Osteoarchaeology, 3, 283-287.

Mikhajlova, E. 2014a. = Михайлова Е. Р. Вещевой комплекс культуры псковских длинных курганов: типология и хронология. Lambert Academic Publishing, Saarbrücken.

Mikhajlova, E. 2014b. = Михайлова Е. Р. Бескурганные могильники близ Которского погоста: хронология и место среди погребальных древностей лесной полосы Восточной Европы. - Русь в IX-X вв.: Общество, государство, культура. Еds Н. А. Макаров \& А. Е. Леонтьев. Сотр. И. Е. Зайцева. Институт археологии РАН, Москва; Древности Севера, Вологда, 317-335.

Mikhajlova, E. 2015a. = Михайлова Е. Р. Литые пластинчатые браслеты с продольным ребром: распространение и хронология на северо-западе Восточной Европы. - Археология и история Пскова и Псковской земли, 30. Еd. Н. В. Лопатин. Нестор-история, Псков, Санкт-Петербург, 259-269.

Mikhajlova, E. 2015b. = Михайлова Е. Р. К реконструкции женского убора из погребений культуры псковских длинных курганов. - Лесная и лесостепная зоны Восточной Европы в эпохи римских влияний и Великого переселения народов. Конференция 4, часть 1. Eds A. М. Воронцов $\&$ И. О. Гавритухин. Государственный музей-заповедник "Куликово поле", Тула, 142-162.

Mikhajlova, E. \& Fedorov, I. 2011. = Михайлова Е. Р. \& Федоров И. А. Случайные находки у пос. Коммунар Ленинградской области - предполагаемый могильник I тыс. н.э. - Археология и история Пскова и Псковской земли. Вып. 26. Еd. И. К. Лабутина. Москва, Псков, 69-77.

Mikhajlova, E., Shmelev, K. \& Gerasimov, D. 2017. = Михайлова Е. Р., Шмелев К. В. \& Герасимов Д. Г. Новый погребальный памятник эпохи великого переселения народов в междуречье Луги и Нарвы. - Ранний железный век Евразии от рубежа эр до середины I тыс. н.э. Динамика освоения культурного пространства. Материалы IV научной конференции “Археологические источники и культурогенез”. Ed. Д. Г. Савинов. Скифия-принт, СанктПетербург, 42-43.

Myts, V., Lysenko, A., Shchukin, M. \& Sharov, O. 2006. = Мыц В. Л., Лысенко А. В., Щукин М. Б. \& Шаров О. В. Чатыр-Даг - некрополь римской эпохи в Крыму. Нестор-История, СанктПетербург.

Orlov, S. 1968. = Орлов С. Н. Археологические исследования в низовьях р. Мсты. - Советская археология, 3, 160-171.

Platonova, N. 1996. = Платонова Н. И. О “белых пятнах” на археологической карте и новом типе памятников третьей четверти I тыс. н.э. на Северо-Западе. - Ладога и Северная Европа. Вторые Чтения памяти Анны Мачинской. Материалы к чтениям. Еd. Д. А. Мачинский. СанктПетербург, 9-12.

Platonova, N. 2002. = Платонова Н. И. О погребальном обряде верхнелужских сопок (по материалам Передольского погоста). - Ладога и ее соседи в эпоху средневековья. Еd. А. Н. Кирпичников. ИИМК РАН, Санкт-Петербург, 181-195. 
Plavinski, M. 2017. = Плавінскі М. А. Курганны могільнік Пагошча ў кантэксце сінхронных старажытнасцей Браслаўскага Паазер'я. Издательство А. М. Янушкевіч, Минск.

Plotkin, K. 1989. = Плоткин К. М. Округа Пскова накануне и в период становления города. Становление европейского средневекового города. Ed. В. В. Седов. Наука, Москва, 159-186.

Reimer, P. J., Bard, E., Bayliss, A., Beck, J. W., Blackwell, P. G., Bronk Ramsey, C., Grootes, P. M., Guilderson, T. P., Haflidason, H., Hajdas, I., Hatt, Ž. C., Heaton, T. J., Hoffmann, D. L., Hogg, A. G., Hughen, K. A., Kaiser, K. F., Kromer, B., Manning, S. W., Niu, M., Reimer, R. W., Richards, D. A., Scott, E. M., Southon, J. R., Staff, R. A., Turney, C. S. M. \& van der Plicht, J. 2013. IntCal13 and Marine13 radiocarbon age calibration curves $0-50,000$ years cal BP. Radiocarbon, 55: 4, 1869-1887.

Rosentau, A., Muru, M., Kriiska, A., Subetto, D. A., Vassiljev, J., Hang, T., Gerasimov, D., Nordqvist, K., Ludikova, A., Lõugas, L., Raig, H., Kihno, K., Aunap, R. \& Letyka, N. 2013. Stone Age settlement and Holocene shore displacement in the Narva-Luga Klint Bay area, eastern Gulf of Finland. - Boreas, 42: 4, 912-931.

Ryabchuk, D. V., Sergeev, A. Yu., Gerasimov, D. V., Kriiska, A., Nordqvist, K., Budanov, L. M., Kovaleva, O. A., Zhamoida, V. A., Anisimov, M. A. \& Terekhov, A. V. 2019. New data on the postglacial development of Narva-Luga Klint Bay (eastern Gulf of Finland): results of geoarchaeological research. - Journal of Coastal Conservation, 23, 727-746.

Sedov, V. 1974. = Седов В. В. Длинные курганы кривичей. (Свод археологических источников CCCP, EI-8.) Наука, Москва.

Sedov, V. 2007. = Седов В. В. Изборск в раннем средневековье. Наука, Москва.

Shcheglova, О. 2004. = Щеглова О. А. Тисненые изделия и инструменты для их изготовления в раннесредневековых Любше, Ладоге и Изборске. - Восточная Европа в средневековье: К 80 летию Валентина Васильевича Седова. Еd. Н. А. Макаров. Наука, Москва, 263-271.

Tvauri, A. 2012. The Migration Period, Pre-Viking Age, and Viking Age in Estonia. Tartu University Press, Tartu.

Yakovlev, А. 1999. = Яковлев А. В. Памятник круга ранних каменных могильников в Выбутах близ Пскова. - Древности Пскова. Археология. История. Архитектура. К юбилею Инги Константиновны Лабутиной. Еd. В. В. Седов. Псков, 167-173.

Yushkova, М. 2015. = Юшкова М. А. Новая группа памятников I-VII вв. на юго-западе Ленинградской области. (Археологические вести, 21.) Дмитрий Буланин, Санкт-Петербург, 187-198.

\author{
Elena R. Mikhaylova, Ivan G. Shirobokov, Kirill V. Shmelev, \\ Gleb K. Danilov, Aivar Kriiska ja Dmitriy V. Gerasimov
}

\title{
LUIDETELE MAETUD: RAHVASTERÄNNUAEGNE PÕLETUSMATUS ROSSON 11 NARVA-LUGA JÕGEDEVAHELISEL ALAL
}

\section{Resümee}

2013. aastal leiti Venemaa ja Eesti piirilt Narva-Luga jõgedevaheliselt alalt Läänemere muistselt osaliselt luidestunud liivastelt rannamoodustistelt (jn 1-2, $4,10)$ põletusmatus. Põlenud inimluud koos esemeleidudega avastati maastikuseire käigus ulatuslikule metsapõlengule (jn 3) järgnenud puude istutuse kraavist (jn 5-6) kõrguselt 7 m ü.m. Koht (Rosson 11 - vastavalt seire käigus leitud muististe järjekorrale) paikneb tasasel alal Kudruküla seljandikul umbes $1 \mathrm{~km}$ kaugusel 
Soome lahest ja umbes 1,5 km kaugusel Rossoni jõest. 2013. aastal tehti leiukohal väljakaevamisi $4 \mathrm{~m}^{2}$ ja 2015. aastal $120 \mathrm{~m}^{2}$ suurusel alal (jn 7-9, 12). Need tööd osutasid, et seal on paiknenud vaid üks haud. Kõik in situ asetsenud savinõukillud ja põlenud inimluud paiknesid $60 \times 60 \mathrm{~cm}$ suurusel muust pinnasest veidi tumedama värvuse ning suurema orgaanikasisalduse poolest eristunud laigul, mille keskosa oli istutuskraavi rajamisel täielikult hävitatud (jn 9).

Inimluud (kokku 87,5 g) on fragmentaarsed ja halvasti määratavad. Need pärinevad 15 kuni 45 aasta vanusest inimesest, tõenäoliselt naisest. Koos inimluudega leiti neli väikest käsitsi valmistatud savinõukildu, raudeseme katke ja vasesulamist ehete põlemisjälgedega katkeid, sh pronksist plaatkaunistus ning kitsa valatud käevõru sulanud katked (jn 13-15). Kuna uuritud alalt ei leitud tuletegemise jälgi, siis võib arvata, et põlenud luud ja esemed toodi paigale kaugemalt ning maeti tõenäoliselt saviurnis maapinda kaevatud madalasse lohku. Ühest põlenud inimluust tehtud radiosüsinikuanalüüs dateerib matuse aastatega 420-560 $(1561 \pm 27 \mathrm{BP}$, UBA-29063). Ka käevõrukatkete tüpokronoloogiline dateering kattub osaliselt selle ajavahemikuga.

Rosson 11 üksik põletusmatus erineb nii Venemaa Isuri platoole kui ka suuremale osale Eesti alale iseloomulikest kivikalmetest, samuti nn Pihkva pikkkääbaste rühmale iseloomulikest liivakääbastest läänepoolsel Venemaal ja idapoolses Eestis ning Lätis (jn 1), kuigi sealt leitud käevõrul on nendelt aladelt häid vasteid (jn 16). Matmiseks valitud koht on üpris kummaline ja osutab pigem ajutisele kui püsivale Rossoni piirkonna kasutamisele Ingerimaa elanike poolt I aastatuhande keskel pKr. 